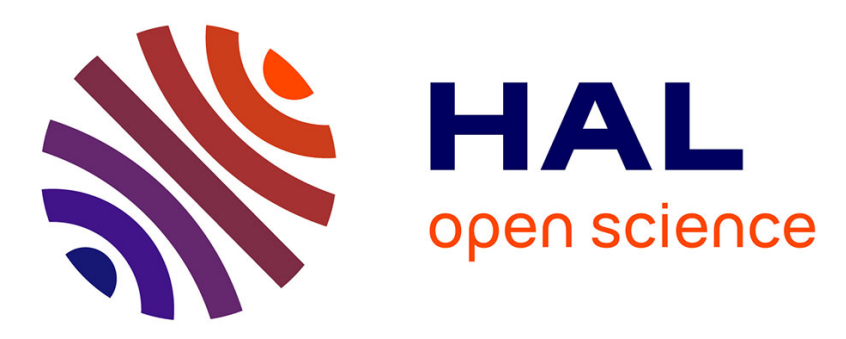

\title{
Biotransformation of halogenated compounds by lyophilized cells of Rhodococcus erythropolis in a continuous solid-gas biofilter
}

Benjamin Erable, Thierry Maugard, Isabelle Goubet, Sylvain Lamare, Marie Dominique Legoy

\section{- To cite this version:}

Benjamin Erable, Thierry Maugard, Isabelle Goubet, Sylvain Lamare, Marie Dominique Legoy. Biotransformation of halogenated compounds by lyophilized cells of Rhodococcus erythropolis in a continuous solid-gas biofilter. Process Biochemistry, 2005, vol. 40, pp.45-51. 10.1016/j.procbio.2003.11.031 . hal-00782060

\section{HAL Id: hal-00782060 https://hal.science/hal-00782060}

Submitted on 29 Jan 2013

HAL is a multi-disciplinary open access archive for the deposit and dissemination of scientific research documents, whether they are published or not. The documents may come from teaching and research institutions in France or abroad, or from public or private research centers.
L'archive ouverte pluridisciplinaire HAL, est destinée au dépôt et à la diffusion de documents scientifiques de niveau recherche, publiés ou non, émanant des établissements d'enseignement et de recherche français ou étrangers, des laboratoires publics ou privés. 


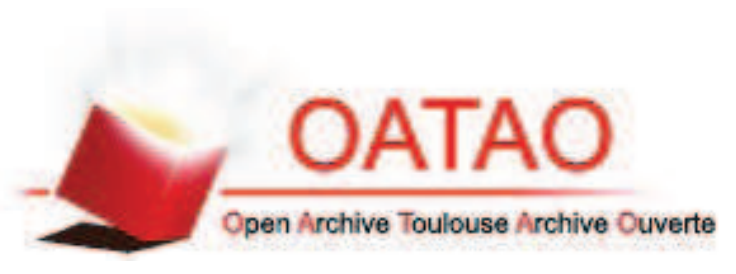

\section{Open Archive Toulouse Archive Ouverte (OATAO)}

OATAO is an open access repository that collects the work of Toulouse researchers and makes it freely available over the web where possible.

This is an author-deposited version published in: http://oatao.univ-toulouse.fr/ Eprints ID: 7878

To link to this article: DOI:10.1016/j.procbio.2003.11.031

URL: http://dx.doi.org/10.1016/j.procbio.2003.11.031

\section{To cite this version:}

Erable, Benjamin and Maugard, Thierry and Goubet, Isabelle and Lamare, Sylvain and Legoy, Marie Dominique Biotransformation of halogenated compounds by lyophilized cells of Rhodococcus erythropolis in a continuous solid-gas biofilter. (2005) Process Biochemistry, vol. 40 ( $\mathrm{n}^{\circ}$ 1). pp. 45-51. ISSN 1359-5113

Any correspondence concerning this service should be sent to the repository administrator: staff-oatao@listes.diff.inp-toulouse.fr 


\title{
Biotransformation of halogenated compounds by lyophilized cells of Rhodococcus erythropolis in a continuous solid-gas biofilter
}

\author{
Benjamin Erable, Thierry Maugard*, Isabelle Goubet, \\ Sylvain Lamare, Marie Dominique Legoy \\ Laboratoire de Génie Protéique et Cellulaire, EA3169, Bâtiment Marie Curie, Université de La Rochelle, \\ Avenue Michel Crépeau, 17042 La Rochelle Cedex 1, France
}

\begin{abstract}
The irreversible hydrolysis of 1-chlorobutane to 1-butanol and $\mathrm{HCl}$ by lyophilized cells of Rhodococcus erythropolis NCIMB 13064, using a solid-gas biofilter, is described as a model reaction. 1-Chlorobutane is hydrolyzed by the haloalkane dehalogenase from $R$. erythropolis. A critical water thermodynamic activity $\left(a_{\mathrm{w}}\right)$ of 0.4 is necessary for the enzyme to become active and optimal dehalogenase activity for the lyophilized cells is obtained for a $a_{\mathrm{w}}$ of 0.9 . A temperature of reaction of $40{ }^{\circ} \mathrm{C}$ represents the best compromise between stability and activity. The activation energy of the reaction was determined and found equal to $59.5 \mathrm{~kJ} / \mathrm{mol}$. The absence of internal diffusional limitation of substrates in the biofilter was observed. The apparent Michaelis-Menten constants $K_{\mathrm{m}}$ and $V_{\max }$ for the lyophilized cells of $R$. erythropolis were 0.011 (1-chlorobutane thermodynamic activity, $a_{\mathrm{ClBut}}$ ) and $3.22 \mu$ moles $/ \mathrm{min} \mathrm{g}$ of cell, respectively. The activity and stability of lyophilized cells were dependent on the quantity of $\mathrm{HCl}$ produced. Since possible modifications of local $\mathrm{pH}$ by the $\mathrm{HCl}$ product, $\mathrm{pH}$ control by the addition of volatile Lewis base (triethylamine) in the gaseous phase was employed. Triethylamine plays the role of a volatile buffer that controls the local $\mathrm{pH}$ and the ionization state of the dehalogenase and prevents inhibition by $\mathrm{Cl}^{-}$. Finally, cells broken by the action of the lysozyme, were more stable than intact cells and more active. An initial reaction rate equal to $4.5 \mu \mathrm{moles} / \mathrm{min} \mathrm{g}$ of cell was observed.
\end{abstract}

Keywords: Haloalkane dehalogenase; Rhodococcus erythropolis; Solid-gas; Biofilter; Bioremediation

\section{Introduction}

Volatile organic compounds (VOCs) are widely used in (and produced by) both industrial and domestic activities. Their extensive use results in their occurrence in aquatic, soil and atmospheric environments. Many VOCs are toxic, and some are considered to be carcinogenic, mutagenic, or teratogenic. Emissions of VOCs also contributes to localized pollution problems of toxicity and odor $[1,2]$.

Among the VOCs, halogenated organic compounds constitute one of the largest groups of environmental pollutants as a result of their widespread use as herbicides, insecticides, fungicides, solvents, plasticizers, intermediates for chemical syntheses [3]. Because of their toxicity, the biodegradation of these compounds has been widely studied. These compounds are quoted by the US Environmental Protec-

\footnotetext{
* Corresponding author. Tel.: +33-5-46-45-82-77; fax: $+33-5-46-45-82-65$.

E-mail address: tmaugard@univ-lr.fr (T. Maugard).
}

tion Agency as priority environmental toxic pollutants [4,5]. Bioremediation via microbial decontamination, is one natural solution to this environmental problem. The biotechnological approach to polluted air bioremediation is now a promising field of research which can supply reliable, simple and cheap technologies for preventing air contamination [6].

The carbon-halogen bond can be cleaved by enzymic dehalogenation, catalyzed by specific dehalogenases. Six mechanisms of dehalogenation are known so far: reductive dehalogenation, oxygenolytic dehalogenation, thiolytic dehalogenation, intramolecular substitution, dehydrohalogenation and hydrolytic dehalogenation. In the course of hydrolytic dehalogenation reactions, catalyzed by halidohydrolases, the halogen substituent is replaced by an hydroxyl group $[7,8]$.

Rhodococcus sp. are known to play a significant role in the biodegradation of VOCs in the environment and are believed to be important for future bioremediation processes. The bacterium $R$. erythropolis can utilize a wide range of 1-haloalkanes as sole carbon source. Short chained 
1-chloroalkanes $\left(\mathrm{C}_{2}\right.$ to $\left.\mathrm{C}_{8}\right)$ appear to be metabolized by the initial action of an hydrolytic dehalogenase (E.C. 3.8.1.5) to form the corresponding alcohol $[9,10]$. Haloalkane dehalogenases are the only enzymes known to be capable of direct hydrolytic dehalogenation of halogenated compounds, without the requirement of coenzymes or oxygen and are thus attractive catalysts for the biotransformation of volatile halogenated organic compounds.

Because many halogenated compounds have low solubility in water, processing in non-conventional media insuring the transformation of halogenated compounds has a potential for waste treatment purposes. Biocatalysis in non-conventional media, especially in a solid-gas system, presents numerous advantages over the conventional liquidsolid system: (i) problems of solubility of substrates and products do not exist and the addition of solvents can be avoided, (ii) the recovery of the biocatalyst is simplified either for batch or continuous reactors, (iii) diffusion in the gaseous phase is more efficient than in solution, thus mass transfers are more efficient) $[11,12]$. Recently, we have reported the possibility of using lyophilized cells in a solidgas bioreactor to transform volatile organic compounds and especially alcohols, aldehydes and ketones using lyophilized baker's yeast (Saccharomyces cerevisiae) [13,14].

The aim of this study is to investigate the ability of lyophilized cells of $R$. erythropolis to transform halogenated compounds, especially 1-chlorobutane, in a continuous solid-gas biofilter.

\section{Materials and methods}

\subsection{Microorganism, culture conditions and chemical material}

$R$. erythropolis NCIMB 13064, was obtained from the National Collection of Industrial and Marine Bacteria, Aberdeen, Scotland.

The organism was grown in $1000 \mathrm{ml}$ flasks containing $200 \mathrm{ml}$ of minimal medium described by Radwan and Al-Muteirie [15] at $\mathrm{pH} 7$ and $200 \mu \mathrm{l}$ of 1-chlorobutane as sole carbon source. Cultures were incubated at $28^{\circ} \mathrm{C}$ on an orbital shaker $(160 \mathrm{rpm})$. Cell growth was monitored by measuring the optical density at $690 \mathrm{~nm}$. After $48 \mathrm{~h}$ of growth, cells were harvested by centrifugation at $7000 \mathrm{rpm}$ for $10 \mathrm{~min}$. The cell paste was washed by resuspension in Tris- $\mathrm{HCl}$ buffer $50 \mathrm{mM} \mathrm{pH} 9$ and lyophilized prior their use in the solid-gas biofilter. All substrates were purchased from Sigma Chemical Co. or Aldrich (USA). Pure water was obtained via a Milli Q system (Millipore, France).

\subsection{Treatment of cells with lysozyme}

In order to break down cell walls, part of cells were treated with lysozyme: $200 \mathrm{mg}$ of lysozyme were added to $600 \mathrm{mg}$ of harvested cells suspended in $30 \mathrm{ml}$ of Tris- $\mathrm{HCl}$ buffer,
$50 \mathrm{mM} \mathrm{pH}$ 9. After $15 \mathrm{~min}$ incubation at $22^{\circ} \mathrm{C}$, this preparation was then frozen at $-20^{\circ} \mathrm{C}$ and lyophilized. Lysozyme was obtained from Sigma Chemical Co. (USA).

\subsection{Solid-gas biofilter}

The solid-gas biofilter used in this study has been previously described by Lamare and Legoy [16]. It is composed of a $9 \mathrm{~cm}$ long glass tube in which the lyophilized cells of $R$. erythropolis are packed between two layers of glass wool. Substrate feeding was obtained by flowing nitrogen, as carrier gas, through the substrate saturation flasks. Substrates were continuously passed through the biofilter and reacted with the lyophilized cells of Rhodococcus erythropolis. The gas leaving the biofilter was analyzed by gas chromatography. Acquisition and control of operating parameters (substrate thermodynamic activity, water thermodynamic activity $\left(a_{\mathrm{W}}\right)$, temperature and pressure) were monitored on line.

A typical experiment was run at $40^{\circ} \mathrm{C}$, with $100 \mathrm{mg}$ of lyophilized cell. The total flow passing into the biofilter was $500 \mu \mathrm{moles} / \mathrm{min}$. 1-Chlorobutane thermodynamic activity $\left(a_{\mathrm{ClBut}}\right)$ was fixed at 0.06 and the $a_{\mathrm{w}}$ at 0.8 . Under these conditions, less than 5\% substrate were converted allowing the assumption that initial rates (expressed in $\mu$ moles of 1-butanol produced per minute and per gram of cell) were measured.

\subsection{Chromatographic analysis}

For these analyses, the vapor phase leaving the biofilter was sampled using a $250 \mu$ l loop on a 6-way valve (Valco) maintained at $190^{\circ} \mathrm{C}$. Samples were automatically injected in the split injector of a gas chromatograph (Agilent model 5890 A) equipped with a Flame Ionization Detector (FID) for detection. The column used was a OV 1701 fused silica capillary column $(25 \mathrm{~m} \times 0.25 \mathrm{~mm}$ i.d. $\times 0.25 \mu \mathrm{m}$ film thickness; Chrompack, France). The split ratio was 43.2/2.7. The injector was kept at $200^{\circ} \mathrm{C}$ and the detector at $250{ }^{\circ} \mathrm{C}$. The column temperature was held at $40^{\circ} \mathrm{C}$ for $2.5 \mathrm{~min}$, then programmed to increase at $15^{\circ} \mathrm{C} / \mathrm{min}$ to $110^{\circ} \mathrm{C}$ and kept for $1 \mathrm{~min}$ at this temperature. The carrier gas was nitrogen and the flow rate in the column was $2.7 \mathrm{ml} / \mathrm{min}$. Hydrogen and air, were supplied to the FID at 38 and $398 \mathrm{ml} / \mathrm{min}$, respectively. Quantitative data were obtained after integration on an HP 3396A integrator. An external standard method was used for the calculations.

\section{Results and discussion}

\subsection{Continuous hydrolysis of 1-chlorobutane by lyophilized cells of $R$. erythropolis in solid-gas biofilter}

Recently, Dravis et al. [17], have reported the possibility of using free lyophilized haloalkane dehalogenase in a solid-gas system to transform 1-chlorobutane. In the study, 


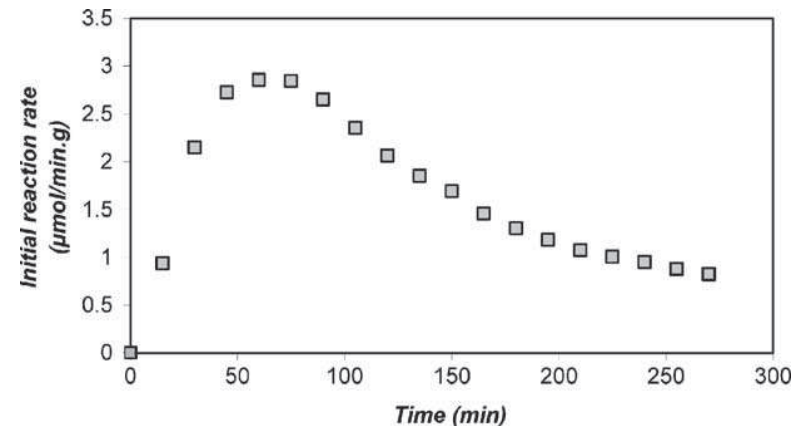

Fig. 1. Initial reaction rate of the hydrolysis of 1-chlorobutane catalyzed by $R$. erythropolis. The reaction was carried out at $40^{\circ} \mathrm{C}$ with $100 \mathrm{mg}$ of cells. The total flow passing into the biofilter was $500 \mu \mathrm{moles} / \mathrm{min}$. 1-Chlorobutane activity was fixed at 0.06 and $a_{\mathrm{W}}$ at 0.8 .

lyophilized cells of $R$. erythropolis were used to carry out the irreversible hydrolysis of 1-chlorobutane to 1-butanol and $\mathrm{HCl}$. In a first reaction, $100 \mathrm{mg}$ of lyophilized cells of $R$. erythropolis were placed at $40^{\circ} \mathrm{C}$ in the solid-gas biofilter. The total flow passing into the biofilter was fixed at $500 \mu \mathrm{moles} / \mathrm{min}$. $a_{\mathrm{ClBut}}$ was fixed at 0.06 (corresponding to $7.8 \mu \mathrm{moles} / \mathrm{min}$ at $40^{\circ} \mathrm{C}$ ) and $a_{\mathrm{W}}$ at 0.8 (corresponding to $33.8 \mu \mathrm{moles} / \mathrm{min}$ at $40^{\circ} \mathrm{C}$ ). The thermodynamic activity of each compound $\mathrm{X}$ in the reactor is calculated as follows:

$a_{\mathrm{X}}=\frac{P p_{\mathrm{X}}}{P p_{\mathrm{X}}^{\mathrm{Sat}}}$

with $P p_{\mathrm{X}}$ is the partial pressure of compound $\mathrm{X}$ in the gas entering the biofilter, $P p_{\mathrm{X}}^{\mathrm{Sat}}$ the saturation vapor pressure of compound X (atm).

As shown in Fig. 1, the initial rate of 1-butanol formation corresponding to dehalogenation of 1-chlorobutane, increases up to a maximum equal to $3 \mu$ moles $/ \mathrm{min} g$ of cell corresponding to $38 \%$ of 1 -chlorobutane conversion. Then, the initial rate of 1-butanol formation decreases to reach a steady state close to $0.6 \mu \mathrm{moles} / \mathrm{min} \mathrm{g}$ of cell. This experiment shows for the first time, that lyophilized cells of $R$. erythropolis can be used in solid-gas biofilter to transform halogenated compounds such as 1-chlorobutane. The ability of $R$. erythropolis cells to convert a wider range of chlorinated and brominated substrates into their corresponding alcohol was then examined.

\subsection{Biotransformation of other halogenated substrates}

Since $R$. erythropolis haloalkane dehalogenase is known to be able to convert numerous halogenated compounds into alcohols [18], the ability of dehydrated cells of this bacteria to transform several halogenated compounds was tested. The reactor, packed with $100 \mathrm{mg}$ of cells, was fed with 1-chlorobutane, 1-chloropentane, 1-chlorohexane, 1-bromobutane or 1-bromohexane at a 0.06 thermodynamic activity. The reactor was maintained at $40{ }^{\circ} \mathrm{C}$ and $a_{\mathrm{w}}$ was fixed at 0.8 and the total flow passing in the solid-gas biofilter was fixed at $500 \mu$ moles/min for all experiments.
Table 1

Haloalkane dehalogenase activity in cell measured on various halogenated substrates $^{\text {a }}$

\begin{tabular}{lc}
\hline Substrate & Relative activity (\%) \\
\hline 1-Chlorobutane & 100 \\
1-Chloropentane & 186 \\
1-Chlorohexane & 194 \\
1-Bromobutane & 98 \\
1-Bromohexane & 301 \\
\hline
\end{tabular}

a Dehalogenase activity was standardized with respect to the 1 -chlorobutane dehalogenation rate, which was $3 \mu$ moles $/ \mathrm{ming}$. The total flow passing into the biofilter was $500 \mu \mathrm{moles} / \mathrm{min}$. The halogenated substrate activity was fixed at 0.06 and the $a_{\mathrm{w}}$ at 0.8 . The reaction was carried out at $40^{\circ} \mathrm{C}$ with $100 \mathrm{mg}$ of cells.

Maximal initial rates observed are reported in Table 1. Results are expressed as percentages of conversion of 1-chlorobutane conversion rate. Dehalogenation was found to be effective, whatever the halogenated compound tested. Moreover, the relative dehalogenase activity of $R$. erythropolis increased as the size of the halogenated compound increased. This could be interesting for depollution since long chain substrates have low solubility in water and are often difficult to remove by classical biofiltration. These experiments confirm the actual possibility of biologically removing halogenated substrates from air streams through a solid-gas biofilter.

The effects of various parameters on the initial rate of dehalogenation was next examined in order to define optimal conditions.

\subsection{Effect of R. erythropolis amount}

The effect of $R$. erythropolis on the initial rate of the biotransformation was studied. Between 0 and $200 \mathrm{mg}$ of lyophilized cells of $R$. erythropolis were placed at $40^{\circ} \mathrm{C}$ in the solid-gas biofilter. The total flow passing into the biofilter was fixed at $500 \mu \mathrm{moles} / \mathrm{min}, a_{\mathrm{ClBut}}$ was fixed at 0.06 and $a_{\mathrm{w}}$ at 0.8 . The initial reaction rate of 1-chlorobutane transformation increased almost linearly over the range investigated (Fig. 2) indicating that internal diffusion of substrates was higher than hydrolytic reaction rates.

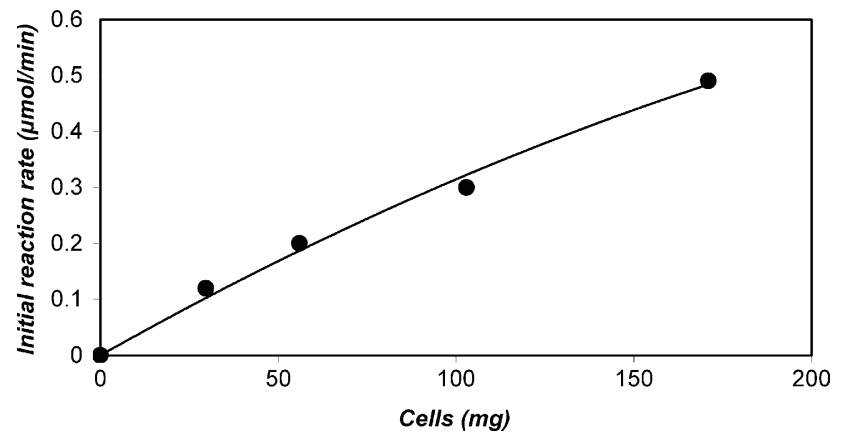

Fig. 2. Initial reaction rate of the hydrolysis of 1-chlorobutane as a function of amount of cells of $R$. erythropolis. The reaction was carried out at $40^{\circ} \mathrm{C}$. The total flow passing into the biofilter was $500 \mu \mathrm{moles} / \mathrm{min}$. $a_{\mathrm{ClBut}}$ was fixed at 0.06 and $a_{\mathrm{W}}$ at 0.8 . 


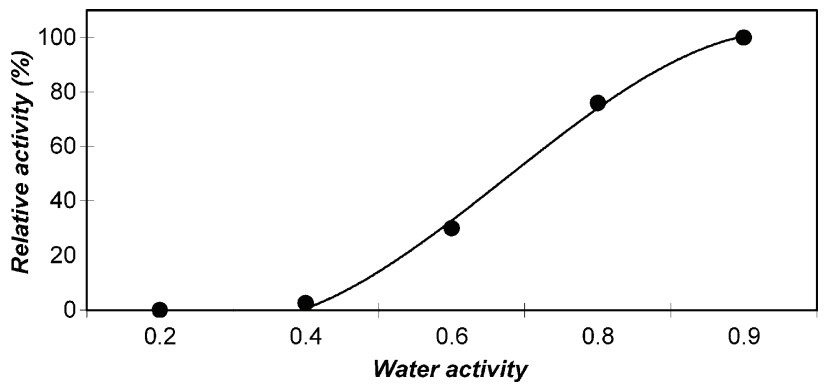

Fig. 3. Effect of $a_{\mathrm{w}}$ on relative activity of $R$. erythropolis. The reaction was carried out at $40^{\circ} \mathrm{C}$ with $100 \mathrm{mg}$ of cells. The total flow passing into the biofilter was $500 \mu \mathrm{moles} / \mathrm{min}$. The $a_{\mathrm{ClBut}}$ was fixed at 0.06 . The maximum initial reaction rate of hydrolysis of 1-chlorobutane was taken as $100 \%$ and was observed for a $0.9 a_{\mathrm{w}}$ value.

Moreover, tests were performed using $100 \mathrm{mg}$ of dehydrated cells grown on nutritive broth without addition of 1-chlorobutane thus presenting a lack in dehalogenase activity (checked by degradation tests). Calibrations curves obtained when increasing 1-chlorobutane activities were identical to those obtained with an empty reactor, meaning that $R$. erythropolis cells do not accumulate 1-chlorobutane. Thus, 1-chlorobutane conversion observed with cells grown on minimal medium supplemented with 1-chlorobutane cannot be attributed to sorption and accumulation of substrates on the biofilter.

\subsection{Water effects}

Free enzyme activity (lipase, cutinase) and the activity of lyophilized cells (baker's yeast) in the gas phase, have been reported to be related to $a_{\mathrm{W}}[13,14,19]$. Reactions were therefore carried out under different $a_{\mathrm{w}}$ conditions. Hundred milligrams of lyophilized cells of $R$. erythropolis were placed at $40{ }^{\circ} \mathrm{C}$ in the solid-gas biofilter. The total flow passing into the biofilter was $500 \mu$ moles $/ \mathrm{min}$. $a_{\mathrm{ClBut}}$ was fixed at 0.06 .

In all experiments, the initial rate of 1-butanol formation increases and reaches a maximum. Then, the initial rate of 1-butanol formation decreases to reach a steady state near to $0.6 \mu \mathrm{moles} / \mathrm{min} \mathrm{g}$ of cell. This maximal rate of 1-butanol formation is strongly influenced by the $a_{\mathrm{W}}$ (Fig. 3). Contrary to the reports of Dravis et al. [17] in which free lyophilized haloalkane dehalogenase was used, the haloalkane dehalogenase in the cells was not able to catalyze the hydrolysis of 1-chlorobutane at low water activities. Indeed, it was observed that a critical $a_{\mathrm{W}}$ of 0.4 was necessary for the dehalogenase of $R$. erythropolis to become active. Over the range of water activities tested, optimal dehalogenase activity for the lyophilized cells was obtained for a $a_{\mathrm{w}}$ of 0.9 . Since water is also a substrate of the reaction, an increase of $a_{\mathrm{W}}$ enhances the rate of biotransformation. Moreover high $a_{\mathrm{w}}$ supports molecular mobility, resulting in a higher reaction rate.

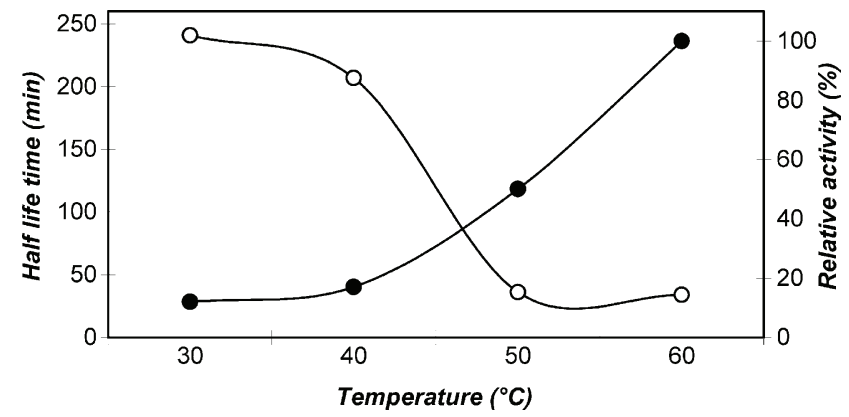

Fig. 4. Effect of temperature on stability $(\bigcirc)$ and relative activity ( of $R$. erythropolis. The reaction was carried out with $100 \mathrm{mg}$ of cells. The total flow passing into the biofilter was $500 \mu \mathrm{moles} / \mathrm{min}$. $a_{\mathrm{ClBut}}$ was fixed at 0.06 and $a_{\mathrm{w}}$ at 0.8 . Half-life is defined as reaction time at which conversion is half of that at the maximum initial reaction rate.

\subsection{Temperature effect}

In order to evaluate the effect of temperature on the thermal stability and dehalogenase activity of lyophilized cells of $R$. erythropolis in the gas phase, a series of reactions was performed at various temperatures. Reactions were carried out with $100 \mathrm{mg}$ of cells. The total flow passing into the biofilter was $500 \mu \mathrm{moles} / \mathrm{min}$. Water and 1-chlorobutane activities were fixed at 0.8 and 0.06 , respectively.

The effect of temperature on the dehalogenase activity of cells was observed over the range $30-60{ }^{\circ} \mathrm{C}$. As shown in Fig. 4, the initial rate of chlorobutane hydrolysis increases with temperature. The optimal temperature to reach the highest initial reaction rate under the selected conditions was $60^{\circ} \mathrm{C}$. Nevertheless, with an increase in activity, the half-life of the lyophilized cells decreases. Forty degree Celsius seems to be the best compromise between the loss of stability and activity since the half-life is about $90 \%$ of that obtained at $30^{\circ} \mathrm{C}$, while activity doubles between 30 and $40^{\circ} \mathrm{C}$.

The activation energy of the reaction as determined by an Arrhenius plot was $59.5 \mathrm{~kJ} \mathrm{~mol}^{-1}$ which is similar to values already reported for haloalkane dehalogenases $[18,20]$.

\subsection{Chlorobutane effects}

The effect of $a_{\mathrm{ClBut}}$ on the dehalogenase activity of $R$. erythropolis was studied. Hundred milligrams of bacteria was placed at $40^{\circ} \mathrm{C}$ in the solid-gas biofilter. The total flow passing into the biofilter was $500 \mu$ moles $/ \mathrm{min}$. The chlorobutane thermodynamic activity was variable while $a_{\mathrm{w}}$ was fixed at 0.8. As shown in Fig. 5A, the maximal reaction rate measured for 1-butanol increases with chlorobutane thermodynamic activity. In the range tested, no inhibitory effect of chlorobutane was detected and the apparent Michaelis-Menten constants $K_{\mathrm{m}}$ and $V_{\max }$ for the lyophilized cells of $R$. erythropolis were determined. In the present case, the $1 / V_{\max }$ axis is not the usual $y$-axis but a

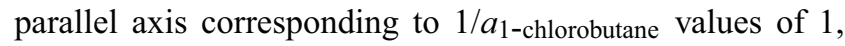




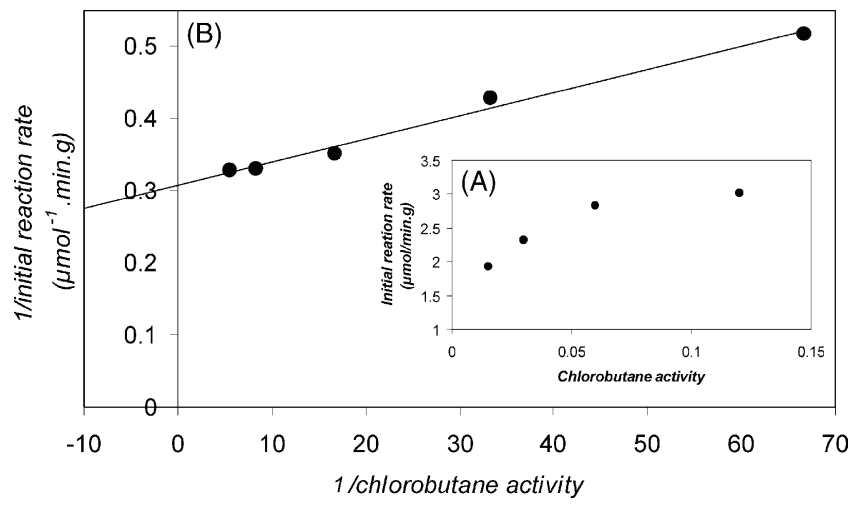

Fig. 5. Initial reaction rate of the hydrolysis of 1-chlorobutane as a function of $a_{\mathrm{ClBut}}(\mathrm{A})$ and reciprocal initial reaction rate of the hydrolysis of 1-chlorobutane vs. reciprocal $a_{\mathrm{ClBut}}$ (B). The reaction was carried out at $40{ }^{\circ} \mathrm{C}$ with $100 \mathrm{mg}$ of cells. The total flow passing into the biofilter was fixed at $500 \mu$ moles $/ \mathrm{min}$ and the $a_{\mathrm{w}}$ at 0.8 .

corresponding to the highest possible value of $a_{1 \text {-chlorobutane }}$. The apparent Michaelis-Menten constants $K_{\mathrm{m}}$ and $V_{\max }$ for the lyophilized cells of $R$. erythropolis have been found to be 0.011 (1-chlorobutane thermodynamic activity) and $3.22 \mu$ moles $/ \mathrm{ming}$ of cell, respectively (Fig. 5B). This apparent $V_{\max }$ observed is eight-fold higher than $V_{\max }$ observed for free lyophilized haloalkane dehalogenase in gas phase by Dravis et al. [17]. This difference can be explained by the experimental conditions which are different. Dravis et al. used a free lyophilized enzyme, in a batch system, at $39^{\circ} \mathrm{C}$, with $a_{\mathrm{w}}$ near to 1 and with 1 -chlorobutane-saturated vapor phase (e.g. $a_{\mathrm{ClBut}}$ near to 1 ). In this study, lyophilized whole cells were used, in a continuous system, at $40{ }^{\circ} \mathrm{C}$, with $a_{\mathrm{w}}$ fixed at 0.8 and with a maximal $a_{\mathrm{ClBut}}$ of 0.12 .

\subsection{Effect of $\mathrm{HCl}$ produced}

In non-conventional media (gaseous system, supercritical fluids, organic solvents, etc.), as in aqueous media, the enzyme activity is dependent on the ionization state of the enzyme. It has been shown that the enzyme activity is dependent on the last aqueous $\mathrm{pH}$ to which the enzyme was exposed prior to drying and suspension in the organic solvent (pH memory) [21,22]. However, acid-base conditions may subsequently change due to acidic or basic reactants (e.g. $[23,24])$.

In order to control the ionization state of enzyme preparation in non-conventional media, buffers can be added to the reaction mixture. These buffers are composed of either an acid and its sodium salt or an amine and its hydrochloride [25-27]. For example, tridodecylamine has been shown to be useful as a basic extractant in several solvents (e.g. extraction of $\mathrm{HCl}$ from the aqueous phase into $n$-decanol).

In this study, the decrease of the dehalogenase activity and the stability of cells observed in all experiments could be attributed to the deactivation of haloalkane dehalogenase by $\mathrm{HCl}$ produced. Indeed, $\mathrm{HCl}$ is considered as a very hydrophilic molecule, which diffuses very slowly through the membrane of cells in non-conventional media. The accumulation of $\mathrm{HCl}$ into the cell during the process could have several roles:

(i) In this study, the cells were prepared at $\mathrm{pH} 9$, which corresponds to optimum $\mathrm{pH}$ of the haloalkane dehalogenase [18]. If $\mathrm{HCl}$ accumulates, the $\mathrm{pH}$ of the microenvironment of the dehalogenase decreases and the dehalogenase activity also decreases.

(ii) $\mathrm{HCl}$ can play the role of inhibitor of the dehalogenase. Indeed, in aqueous solutions, it has been shown that the halides are uncompetitive inhibitors of haloalkane dehalogenase from Rhodococcus sp., and the $K_{i}$ for chloride and bromide was pH-dependent [28]. Consequently, in the reaction of dehalogenation by the haloalkane dehalogenase, the rate-limiting step is the release of the halogen ion from the active site.

In order to confirm the effect of $\mathrm{HCl}$, a non-reactive hydrophobic base (triethylamine) which is not a substrate of the dehalogenase was added under steady state conditions. When the triethylamine is added (thermodynamic activity fixed at 0.05 , corresponding to $3.9 \mu \mathrm{moles} / \mathrm{min} \mathrm{g}$ at $40^{\circ} \mathrm{C}$ ), the conversion of 1-chlorobutane is stimulated and the initial rate of 1-butanol formation increases (Fig. 6). This result confirms that the dehalogenase was not denatured but only inhibited by $\mathrm{HCl}$. This stimulation is not only the result of the increase of the $\mathrm{pH}$ of microenvironment of the enzyme, but also, the result of the increase of the rate of release of the $\mathrm{Cl}^{-}$from the active site, as a result of triethylamine action. The triethylamine would scavenge the $\mathrm{HCl}$ that is produced during reaction. This phenomenon has been already described for the free haloalkane dehalogenase in gas phase [17].

The apparent Michaelis-Menten constants $K_{\mathrm{m}}$ and $V_{\max }$ for the cells of $R$. erythropolis have been measured with several triethylamine activities. An increase of triethylamine

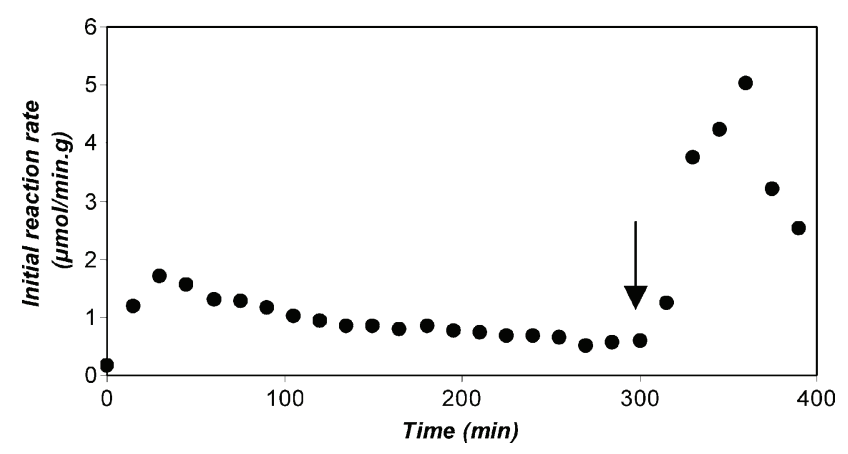

Fig. 6. Continuous initial rate of the hydrolysis of 1-chlorobutane catalyzed by $R$. erythropolis as a function of reaction time. Effect of the triethylamine addition. The total flow passing into the biofilter was $500 \mu \mathrm{moles} / \mathrm{min}$. $a_{\mathrm{ClBut}}$ was fixed at 0.06 and the $a_{\mathrm{w}}$ at 0.6 . The reaction was carried out at $40{ }^{\circ} \mathrm{C}$ with $100 \mathrm{mg}$ of cells. Addition of triethylamine in the gas phase $\left(a_{\mathrm{TEA}}=0.05\right)$ is indicated by the arrow. 


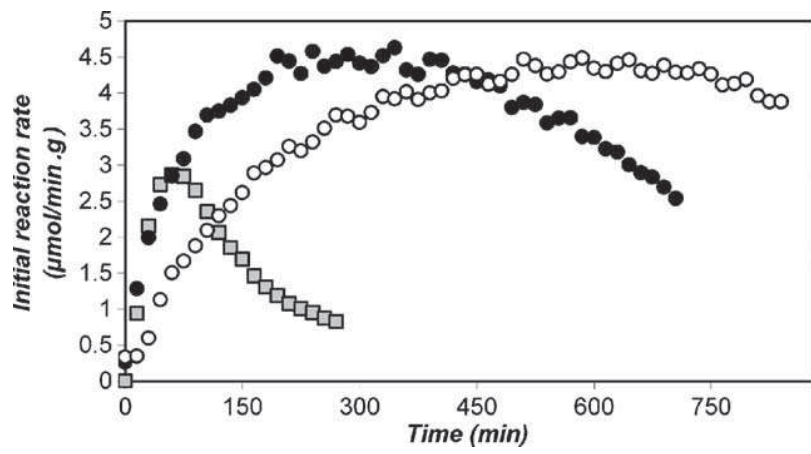

Fig. 7. Continuous initial rate of the hydrolysis of 1-chlorobutane catalyzed by $R$. erythropolis as a function of reaction time. The total flow passing into the biofilter was $500 \mu \mathrm{moles} / \mathrm{min} . a_{\mathrm{ClBut}}$ was fixed at 0.06 and $a_{\mathrm{w}}$ at 0.8 . The reaction was carried out at $40^{\circ} \mathrm{C}$ with $100 \mathrm{mg}$ of untreated cells $(\square)$, cells treated with lysozyme $(-)$, or cells treated with lysozyme and with triethylamine in the gaseous phase $\left(a_{\mathrm{TEA}}=0.12(\bigcirc)\right)$.

thermodynamic activity increases the $V_{\max }$ and decreases the $K_{\mathrm{m}}$. For example, when triethylamine thermodynamic activity was fixed at 0.1 , the $K_{\mathrm{m}}$ and $V_{\max }$ were equal to 0.43 and $9.8 \mu \mathrm{moles} / \mathrm{min} \mathrm{g}$, respectively. This decrease of the affinity could be the result of a steric hindrance of the triethylamine, which prevents access to the catalytic site.

\subsection{Lysozyme effect}

To conclude this study, we carried out a reaction of dehalogenation of 1-chlorobutane with cells, which were first treated by the lysozyme, for breaking down the cell walls of bacteria. Cells treated by lysozyme, were more active and stable over the standard reaction (Fig. 7). The initial rate of 1-butanol formation increases to reach a maximum rate equal to $4.5 \mu \mathrm{moles} / \mathrm{min} \mathrm{g}$ of cell. When the membranes of the cells are broken, $\mathrm{HCl}$ diffuses freely and does not accumulate. The decrease of $\mathrm{pH}$ and the inhibition of the dehalogenase do not occur. Triethylamine and lysozyme combined action, confirms these assumptions. The activity of the enzyme remains equal to $4.5 \mu$ moles $/ \mathrm{min}$ g.

\section{Conclusion}

The possibility of obtaining continuous hydrolysis of halogenated compounds using lyophilized whole cells of $R$. erythropolis in a continuous solid-gas biofilter was demonstrated. Hydrolysis of 1-chlorobutane was studied as a model reaction. The stability and the dehalogenase activity of lyophilized cells of $R$. erythropolis in the biofilter was strongly dependent of various parameters (temperature, substrate thermodynamic activity, water thermodynamic activity, $\mathrm{HCl}$ diffusion and $\mathrm{pH}$ of microenvironment). Dehalogenase activity and the stability of cells were also dependent on $\mathrm{HCl}$ produced. Thus, $\mathrm{pH}$ control by the addition of volatile Lewis base (triethylamine) can be highly beneficial. Triethylamine plays the role of a volatile buffer which controls the ionization state of the dehalogenase and prevents $\mathrm{Cl}^{-}$inhibition. We observed that cells broken by the action of the lysozyme, were more active and more stable than intact cells. In addition, in similar conditions, four other halogenated compounds were hydrolyzed with excellent yield.

\section{References}

[1] Mohamed MF, Kang D, Aneja VP. Volatile organic compounds in some urban locations in United States. Chemosphere 2002;47:86382.

[2] Shah JJ, Singh HB. Distribution of volatile organic chemicals in outdoor and indoor air. Environ Sci Technol 1988;22:1381.

[3] Janssen DB, Van der Ploeg J, Pries F. Genetic and biochemistry of dehalogenating enzymes. Biodegradation 1994;5:249-57.

[4] Belkin S. Biodegradation of haloalkanes. Biodegradation 1992;3: 299-313.

[5] Keith LH, Teilliard WA. Priority pollutants. I. A perspective view. Environ Sci Technol 1979;13:416-23.

[6] Hardman DJ. Biotransformation of halogenated compounds. Crit Rev Biotechnol 1991;11:1-40.

[7] Fetzner S, Lingens F. Bacterial dehalogenases: biochemistry, genetics and biotechnological applications. Microbiol R 1994;58:641-85.

[8] Swanson PE. Dehalogenases applied to industrial-scale biocatalysis. Curr Opin Biotechnol 1999;10:365-9.

[9] Curragh H, Flynn O, Larkin MJ, Stafford TM, Hamilton JTG, Harper DB. Haloalkane degradation and assimilation by $R$. erythropolis NCIMB 13064. Microbiology 1994;140:1433-42.

[10] Franken SM, Rozeboom HJ, Kalk KH, Dijkstra BW. Crystal structure of haloalkane dehalogenase: an enzyme to detoxify halogenated alkanes. EMBO J 1991;10:1297-302.

[11] Lamare S, Legoy MD. Biocatalysis in the gas phase. Trends Biotechnol 1993;11:413-8.

[12] Russell AJ, Yang FX. Catalyzed gas-phase reactions with enzymes. Chemtech 1996;26:24-7.

[13] Goubet I, Maugard T, Lamare S, Legoy MD. Role of water activity and temperature on activity and stability of dried whole cells of Saccharomyces cerevisiae in a continuous solid gas bioreactor. Enzyme Microb Technol 2002;31:425-30.

[14] Maugard T, Lamare S, Legoy MD. Gas phase biotransformation reaction catalyzed by baker's yeast. Biotechnol Bioeng 2001;73: 164-8.

[15] Radwan SS, Al-Muteirie AS. Vitamin requirements of hydrocarbonutilizing soil bacteria. Microbiol Res 2001;155:301-7.

[16] Lamare S, Legoy MD. Working at controlled water activity in a continuous process: the gas/solid system as a solution. Biotechnol Bioeng 1995;45:387-97.

[17] Dravis BC, Lejeune KE, Hetro AD, Russell AJ. Enzymatic dehalogenation of gas phase substrates with haloalkane dehalogenase. Biotechnol Bioeng 2000;69:235-41.

[18] Stafford, TM. The microbial degradation of chloroalkanes. Ph.D. Thesis. The Queens University of Belfast, Belfast, UK, 1993.

[19] Lamare S, Legoy MD. Kinetic studies of a Fusarium solani pisii cutinase used in a gas/solid system. Hydrolysis and transesterification reactions. Biotechnol Bioeng 1997;57:1-8.

[20] Sallis PJ, Armfield SJ, Bull AT, Hardman DH. Isolation and characterisation of a halidohydrolase from $R$. erythropolis Y2. J Gen Microbiol 1990;136:115-20.

[21] Halling PJ. Biocatalysis in low-water media: understanding effects of reaction conditions. Curr Opin Chem Biol 2000;4:74 80.

[22] Zaks A, Klibanov AM. Enzyme-catalyzed processes in organic solvents. Proc Natl Acad Sci USA 1985;82:3192-6. 
[23] Martinelle M, Hult K. Kinetics of acyl transfer reactions in organic media catalysed by Candida antarctica lipase B. Biochim Biophys Acta 1995;1251:191-7.

[24] Maugard T, Remaud-Simeon M, Monsan P. Kinetic study of chemoselective acylation of amino-alditol by immobilized lipase in organic solvent: effect of substrate ionization. BBA 1998;1387:177-83.

[25] Xu K, Klibanov AM. pH control of the catalytic activity of cross-linked enzyme crystals in organic solvents. J Am Chem Soc 1996;118:9815-9.
[26] Blackwood AD, Curran LJ, Moore BD, Halling PJ. Organic phase buffers control biocatalyst activity independent of initial aqueous $\mathrm{pH}$. Biochim Biophys Acta 1994;1206:161-5.

[27] Halling PJ, Blackwood AD, Moore BD. Control of ionization state and activity of enzymes in organic media. Ann NY Acad Sci 1996;799:251-6.

[28] Schindler JF, Naranjo PA, Honaberger DA, Chang CH, Brainard JR, Vanderberg LA, Unkefer CJ. Haloalkane dehalogenases: steady-state kinetics and halide inhibition. Biochemistry 1999;38:5772-8. 